\title{
Mechanistic insight in the ethane dehydrogenation reaction over $\mathrm{Cr} / \mathrm{Al}_{2} \mathrm{O}_{3}$ catalysts
}

\author{
Unni Olsbye $^{\mathrm{a}}$, Anastasia Virnovskaia ${ }^{\mathrm{a}}$, Øystein Prytz ${ }^{\mathrm{a}}$, Stan J. Tinnemans ${ }^{\mathrm{b}}$, and Bert M. Weckhuysen ${ }^{\mathrm{b}, *}$ \\ ${ }^{\mathrm{a}}$ Center for Materials Science and Nanotechnology, Institute of Chemistry, University of Oslo, 1033Blindern, N-0315 Oslo, Norway \\ ${ }^{\mathrm{b}}$ Department of Inorganic Chemistry and Catalysis, Debye Institute, Utrecht University, 800833508 TB Utrecht, The Netherlands
}

Received 20 April 2005; accepted 4 May 2005

\begin{abstract}
A $\mathrm{Cr} / \mathrm{Al}_{2} \mathrm{O}_{3}$ alkane dehydrogenation catalyst exhibits a maximum in ethylene yield during an ethane dehydrogenation cycle. Isotopic labelling experiments with monolabelled ${ }^{13} \mathrm{C}$-ethane and deuterium were used to elucidate whether the initial activity increase could be due to formation of an active, larger hydrocarbon intermediate on the surface. The results strongly indicate that this is not the case, and instead point to a traditional reaction cycle involving adsorption of ethane to form an ethyl species, followed by desorption of ethene and hydrogen. Transient kinetic data suggest that ethane adsorption is the rate-determining step of reaction.
\end{abstract}

KEY WORDS: dehydrogenation; ethane; mechanistic study; $\mathrm{Cr} / \mathrm{Al}_{2} \mathrm{O}_{3}$.

\section{Introduction}

The catalytic production of light alkenes is of key importance to the development of chemical industries since it provides an opportunity to high-purity propylene, which is of direct use in the production of polypropylene. High-loaded $\mathrm{Cr} / \mathrm{Al}_{2} \mathrm{O}_{3}$ catalysts have shown to be very active and selective in this reaction and are industrially used at dehydrogenation plants all over the world [1-3]. The increasing demand for propene due to the growing polypropylene market, the related use of this catalytic system as well as the catalyst complexity have initiated many research activities in both academia and chemical industries. In the last decade a significant amount of knowledge has been gathered regarding the molecular structure of supported chromium oxides, the nature of the active chromium oxide site and the possible short- and longterm deactivation routes [4-10].

Surprisingly, not much studies have been devoted to the elucidation of the reaction mechanism of this industrially important catalytic system. The group of Burwell did seminal work in the 1960s on $\mathrm{Cr}_{2} \mathrm{O}_{3}$ by using D-labelled hydrocarbons and deuterium $\mathrm{D}_{2}$ $[11,12]$. Unfortunately, to our best knowledge, there are no similar studies for supported chromium oxide catalysts. Indeed, only scattered information about the alkane dehydrogenation mechanism is available for chromium-on-alumina and chromium-on-zirconia systems, and none at all for silica-supported chromium oxide catalysts. In all these catalyst systems, a $\mathrm{Cr}-\mathrm{O}$

\footnotetext{
* To whom correspondence should be addressed.

E-mail: unni.olsbye@kjemi.uio.no; b.m.weckhuysen@chem.uu.nl
}

moiety with chromium in its tri- or divalent state is envisaged as the active site for $\mathrm{C}-\mathrm{H}$ activation. Figure 1 shows the dehydrogenation mechanism based on such mononuclear $\mathrm{Cr}^{3+}-\mathrm{O}$ site supported on a high-surface oxide, as recently discussed by Lillehaug et al. [13]. The activation of the $\mathrm{C}-\mathrm{H}$ bond starts with the reaction of the alkane with a coordinatively unsaturated $\mathrm{Cr}^{3+}$ centre leading to the formation of a new $\mathrm{O}-\mathrm{H}$ group and a Cr-alkyl bond. The alkene is then formed as a result from a hydrogen transfer from the alkyl to $\mathrm{Cr}$, and this reaction is thought to be rate determining. The reaction cycle is completed by the formation of $\mathrm{H}_{2}$ and the regeneration of the $\mathrm{Cr}^{3+}-\mathrm{O}$ active site. A possible, parallel mechanism involves addition of ethane to a hydridochromium site, formed in the first cycle, leading to the formation of $\mathrm{Cr}$-Ethyl and molecular $\mathrm{H}_{2}$. The reaction cycle is completed by $\beta$ - $\mathrm{H}$ transfer to $\mathrm{Cr}$ and ethene desorption.

In recent years, it has been suggested that coke deposits could also be active in alkane dehydrogenation reactions. More specifically, it has been shown by the group of Schlogl that carbon nanomaterials are very active catalyst materials in the oxidative dehydrogenation of ethylbenzene to styrene $[14,15]$. This observation is further supported by our own findings that with a $\mathrm{Cr} /$ $\mathrm{Al}_{2} \mathrm{O}_{3}$ catalyst, a maximum in propene yield during a propane dehydrogenation cycle is achieved after about 20 min-on-stream [16-18]. This observation could be explained by initial formation of carbon deposits by the supported chromium oxide species. The formed coke could then possess activity in the dehydrogenation of propane. However, another plausible explanation for this phenomenon could be the enhanced adsorption of propane near the active site once small amounts of coke 


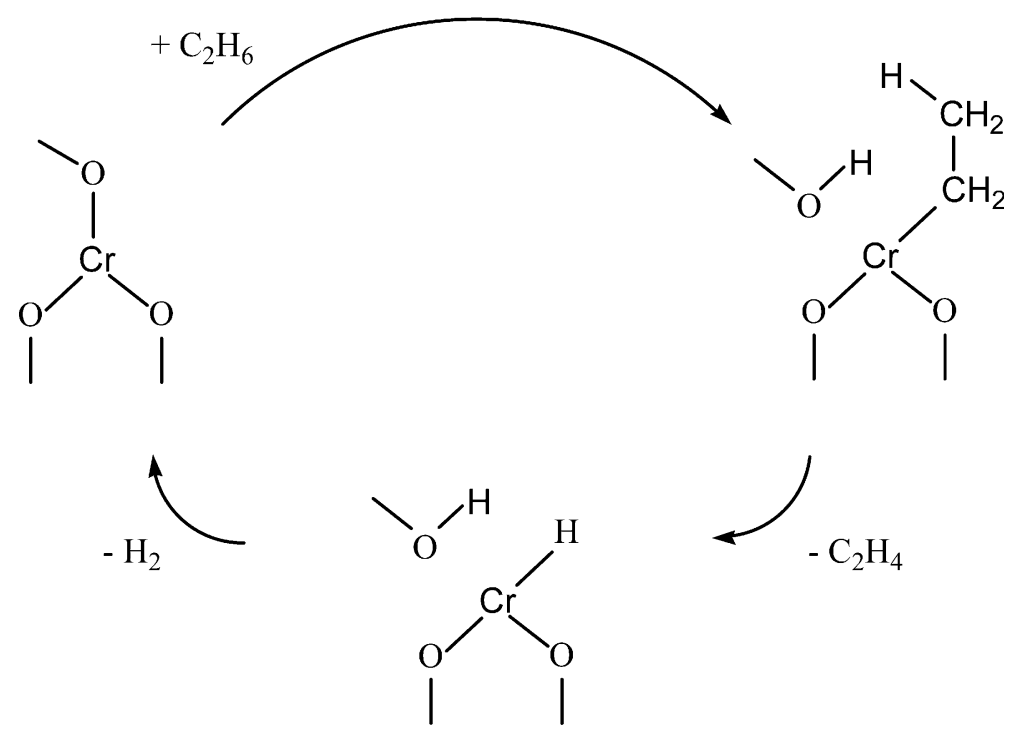

Figure 1. Schematic reaction mechanism for the dehydrogenation of alkanes over a $\mathrm{Cr}^{3+}-\mathrm{O}$ active site.

are formed at the catalyst surface. Once too much coke is formed, the active dehydrogenation site is less accessible and as a consequence the propylene yield decreases.

The goal of this paper is twofold. First of all, we would like to elucidate if carbon deposits are indeed active in the dehydrogenation of ethane. For this purpose, we have conducted isotopic labelling experiments for an ethane dehydrogenating $\mathrm{Cr} / \mathrm{Al}_{2} \mathrm{O}_{3}$ catalyst making use of labelled ${ }^{13} \mathrm{C}$-ethane and deuterium. Secondly, the data obtained allow us to extend the work of Burwell $[11,12]$ to alumina-supported chromium oxide catalysts and discuss the obtained insights in relation with the recently published theoretical study by Lillehaug et al. on the same reaction system [13].

\section{Experimental}

Catalytic tests were carried out in a tubular fixed bed quartz reactor with inner diameter $7 \mathrm{~mm}$. The temperature in the catalyst bed was measured by a thermocouple contained in a quartz thermocouple well (outer diameter $3 \mathrm{~mm}$ ), which was placed directly under the catalyst bed. The alumina-supported chromium oxide catalyst $\left(13 \mathrm{wt} \% \quad \mathrm{Cr} / \mathrm{Al}_{2} \mathrm{O}_{3}, \quad 200 \mathrm{mg}, \quad 0.25-0.42 \mathrm{~mm}\right.$ particle size) was pretreated by heating to $580^{\circ} \mathrm{C}$ in $\mathrm{He}$ stream and exposure to $20 \% \quad \mathrm{O}_{2} / \mathrm{He}$ for $30 \mathrm{~min}$ at $580{ }^{\circ} \mathrm{C}$ before flushing with $\mathrm{He}$. Details of the catalyst system can be found elsewhere [16-18]. Unless otherwise specified, the reaction mixture was composed of $2 \mathrm{Nml} /$ min $\mathrm{C}_{2} \mathrm{H}_{6}$ and $20 \mathrm{Nml} / \mathrm{min} \mathrm{He}$. Catalyst regeneration was performed by exposure to a $20 \% \mathrm{O}_{2} / \mathrm{He}$ stream for $30 \mathrm{~min}$ at $580^{\circ} \mathrm{C}$. Using Brooks mass flow meters the composition of the feed gas was controlled. Transient experiments were performed by switching a 4-way, He-actuated valve (Valco Inc.) between two sets of feed lines, before the reactor. Feed and product gas composition was analyzed by using an on-line HP Quad Micro-Gas Chromatograph (GC) with 3 separate channels containing Molsieve-5A, PoraPlot-U and AluminaPlot columns, respectively, and thermal conductivity detectors. The mass spectrum of the reactor effluent was continuously monitored by using an on-line Pfeiffer Omnistar Mass Spectrometer. The isotopic composition of each gas component was determined by using an off-line HP $6890 \mathrm{GC}$ with a GS GasPro column and a HP 5973 Mass Selective Detector.

Isotopic labeling experiments were performed after pretreatment and exposure to the standard reactant mixture for $10-20 \mathrm{~min}$ at $580{ }^{\circ} \mathrm{C}$, followed by flushing in He. $\mathrm{D}_{2}$ gas $(99.8 \%$ ) was obtained from Linde Gas AG. Monolabelled ethane $\left(1-{ }^{13} \mathrm{C}, 99 \%\right)$ was obtained from Cambridge Isotope Laboratories Inc. Simulated mass fragmentation spectra were calculated by assuming a statistical distribution of corresponding fragments (such as $\mathrm{C}_{2} \mathrm{H}_{3}{ }^{+}$versus $\mathrm{C}_{2} \mathrm{H}_{2} \mathrm{D}^{+}$), not taking into account kinetic isotope effects.

Used $\mathrm{Cr} / \mathrm{Al}_{2} \mathrm{O}_{3}$ catalyst was studied in a JEOL $2010 \mathrm{~F}$ Transmission Electron Microscope (TEM) with a field emission gun operated at $200 \mathrm{kV}$. The microscope was fitted with a Noran Vantage DI + energy dipersive $\mathrm{X}$-ray system. Samples were prepared by crushing in ethanol in an agate mortar and deposited on a carbon film suspended on a copper mesh.

\section{Results}

Typical conversion and selectivity vs. time on stream (TOS) plots for ethane dehydrogenation over $13 \mathrm{wt} \%$ $\mathrm{Cr} / \mathrm{Al}_{2} \mathrm{O}_{3}$ are shown in figure 2. Ethane conversion initially increases, and then slowly decreases, with increasing TOS. Maximum conversion is observed after $15 \mathrm{~min}$ on stream. The ethene selectivity $\left(\begin{array}{ll}\% & \mathrm{C}_{1}\end{array}\right)$ 


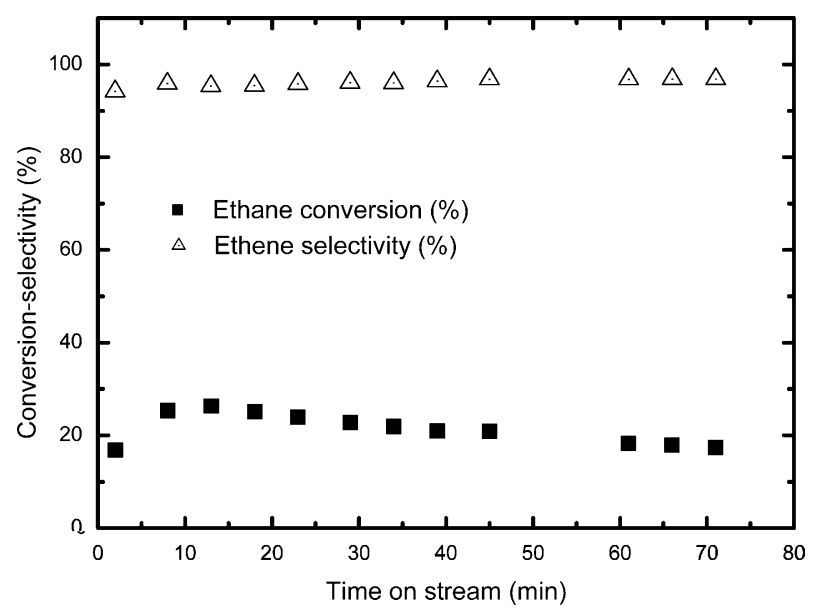

Figure 2. Ethane conversion and ethene selectivity versus time on stream over a $13 \mathrm{wt} \% \mathrm{Cr} / \mathrm{Al}_{2} \mathrm{O}_{3}$ catalyst $(200 \mathrm{mg})$ at $580{ }^{\circ} \mathrm{C}, 1$ atm. Feed gas composition: $\mathrm{C}_{2} \mathrm{H}_{6}: \mathrm{He}=2: 20(\mathrm{Nml} / \mathrm{min})$.

is higher than $94 \%$ throughout the test. Major by-products are methane and $\mathrm{C}_{4}{ }^{+}$hydrocarbons. $\mathrm{CO}_{2}$ formation ( $1 \%$ selectivity) is observed initially, but decreases to undetectable values after $5 \mathrm{~min}$ on stream. This can be explained by the reduction of surface $\mathrm{Cr}^{6+}$ by ethane resulting in the initial formation of $\mathrm{CO}_{2}$.

Mass fragmentation spectra from a $\mathrm{D}_{2}$ addition experiment $\quad\left(\mathrm{C}_{2} \mathrm{H}_{6}: \mathrm{D}_{2}: \mathrm{He}=2: 1: 20 \mathrm{Nml} / \mathrm{min}, \quad 580{ }^{\circ} \mathrm{C}\right.$, $15 \%$ ethane conversion) are shown in figure 3 . The spectra for unlabelled compounds are included for comparison. Simulated mass fragmentation spectra are also shown. The results indicate that only a minor fraction of ethane (4\%) experiences $\mathrm{H}-\mathrm{D}$ exchange, and that only one $\mathrm{H}$ is exchanged for $\mathrm{D}$ in each of the labelled molecules (figure 3a). For ethene, a larger fraction of the molecules contains $\mathrm{D}$. The simulated spectrum indicates that the abundances of ethene are: $89 \% \mathrm{C}_{2} \mathrm{H}_{4}, 10 \% \mathrm{C}_{2} \mathrm{H}_{3} \mathrm{D}, 1 \% \mathrm{C}_{2} \mathrm{H}_{2} \mathrm{D}_{2}$ (figure $3 \mathrm{~b}$ ).

Results from a transient experiment in which the Ethane $/ \mathrm{He}+\mathrm{Ar}$ feed was switched to $\mathrm{He}+\mathrm{Ne}$, are shown in figure 4. A rapid decline in all masses is observed.

Mass fragmentation spectra from an experiment in which the catalyst was first exposed to ${ }^{12} \mathrm{C}$-ethane under standard conditions, then flushed with $\mathrm{He}$ until no 28 peak was observed in the mass spectrometer, and finally exposed to mono-labelled ethane, ${ }^{13} \mathrm{CH}_{3}{ }^{12} \mathrm{CH}_{3}$ $\left(\mathrm{C}_{2} \mathrm{H}_{6}: \mathrm{He}=2: 20 \mathrm{Nml} / \mathrm{min}, 580{ }^{\circ} \mathrm{C}, 20 \%\right.$ ethane conversion), are shown in figure 5 . The mass fragments of ethane (figure 5a) and ethene (figure 5b) are both shifted one mass unit higher after introduction of $1-{ }^{13} \mathrm{C}$ ethane compared to ${ }^{12} \mathrm{C}$ ethane. No change in the fragmentation pattern is observed with time (30-180 s after on-set of the $1-{ }^{13} \mathrm{C}$ ethane feed).

A representative TEM image of the used $\mathrm{Cr} / \mathrm{Al}_{2} \mathrm{O}_{3}$ catalyst is shown in figure $6 . \mathrm{Cr}$ is observed in small crystallites with average diameter around $10 \mathrm{~nm}$. This corresponds to a $\mathrm{Cr}$ dispersion of $14 \%$, assuming that the crystallites are composed of $\mathrm{Cr}_{2} \mathrm{O}_{3}$. Formation of a
$\mathrm{Cr}-\mathrm{O}$ monolayer on the alumina surface, as proposed by Hakuli et al. [16] would further increase the dispersion. EDS analysis could not confirm whether such a layer is present on our catalyst sample.

\section{Discussion}

Recent work on propane dehydrogenation over supported chromium oxide catalysts has indicated that, in addition to $\mathrm{Cr}^{6+}$ reduction, formation of hydrocarbon species on the catalyst surface may contribute to the initial activity increase observed [17-19]. The catalytic test results reported in figure 1 are in line with the previous results, since the activity increase continues after the $\mathrm{CO}_{\mathrm{x}}$ formation has vanished. One of the aims of this work is to elucidate whether the observed activity increase may be related to the formation of active intermediates on the catalyst surface, or whether the mechanism of figure 1 prevails. The results of the transient experiment (figure 4) show that the residence time of any ethene-forming intermediate on the catalyst surface is very short. If an oligomer or aromatic compound were an intermediate in ethene formation, isotopic scrambling of ethene would be expected to occur within the order of seconds during the $1-{ }^{13} \mathrm{C}$ ethane experiment (figure 5). No indication of isotopic scrambling is observed during the first $180 \mathrm{~s}$ after onset of the $1-{ }^{13} \mathrm{C}$ ethane feed. This is most readily seen from the absence of any ${ }^{13} \mathrm{C}_{2} \mathrm{H}_{4}(\mathrm{~m} / \mathrm{z} 30)$ or ${ }^{13} \mathrm{C}_{2} \mathrm{H}_{6}$ formation $(\mathrm{m} / \mathrm{z} 32)$ (The small peaks observed for $\mathrm{m} / \mathrm{z} 30$ and $\mathrm{m} / \mathrm{z} 32$, respectively, correspond to the $1.1 \%$ natural abundance of ${ }^{13} \mathrm{C}$ in carbon). This result strongly suggests that such intermediates are not part of the reaction cycle leading to ethene formation.

The results observed during the ethane- $\mathrm{D}_{2}$ experiments show that only one $\mathrm{H}$ is exchanged for $\mathrm{D}$ in ethane. This observation points to an end-on, dissociative adsorption of ethane on the catalyst surface. This observation is in line with results reported by Burwell 

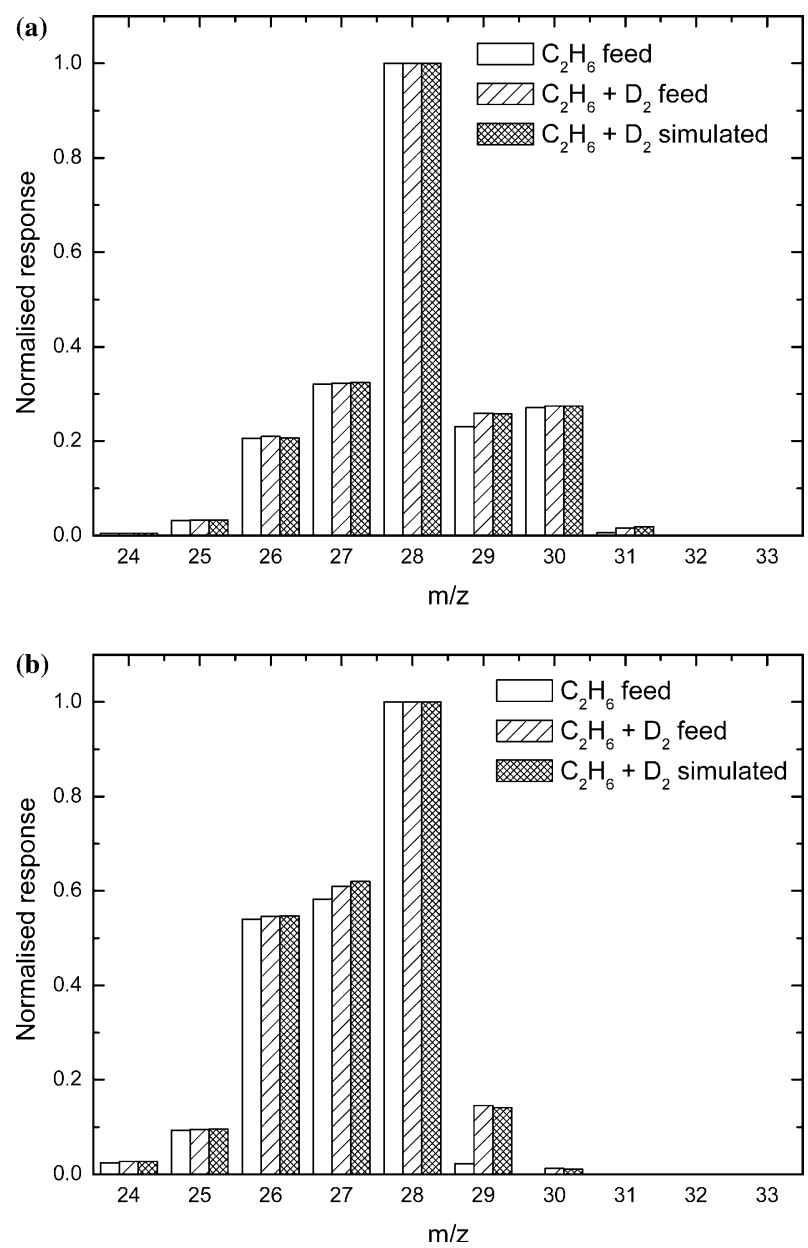

Figure 3. Mass fragmentation pattern of (a) ethane and (b) ethene in the reactor effluent during a dehydrogenation experiment with gas feed composition $\mathrm{C}_{2} \mathrm{H}_{6}: \mathrm{D}_{2}: \mathrm{He}=2: 0: 20$ or $2: 1: 20(\mathrm{Nml} / \mathrm{min})$. Test conditions: $13 \mathrm{wt} \% \mathrm{Cr} / \mathrm{Al}_{2} \mathrm{O}_{3}$ catalyst $(200 \mathrm{mg}), 580{ }^{\circ} \mathrm{C}, 1 \mathrm{~atm}$.

et al. for higher alkanes on $\mathrm{Cr}_{2} \mathrm{O}_{3}[12]$ and the recent theoretical work of Lillehaug et al. [13]. The absence of bi-deuterated ethane, as would be expected for ethene

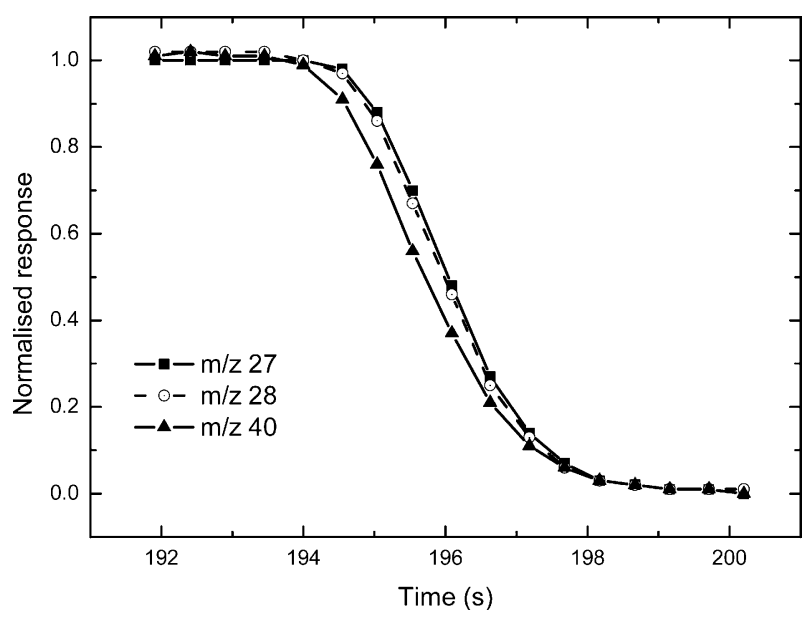

Figure 4. Transient responses observed in the reactor effluent when switching from a $\mathrm{C}_{2} \mathrm{H}_{6}: \mathrm{Ar}: \mathrm{He}=2: 1: 20(\mathrm{Nml} / \mathrm{min})$ to a $\mathrm{Ne}: \mathrm{He}=3: 20$ $(\mathrm{Nml} / \mathrm{min})$ feed over a $13 \mathrm{wt} \% \mathrm{Cr} / \mathrm{Al}_{2} \mathrm{O}_{3}$ catalyst $(200 \mathrm{mg})$ at $580{ }^{\circ} \mathrm{C}$, $1 \mathrm{~atm} . \mathrm{m} / \mathrm{z} 40$ is characteristic of Ar. hydrogenation in the presence of $\mathrm{D}_{2}$ [12], further indicates that there is little back formation of ethane from ethene under the applied reaction conditions. Ethene experiences more $\mathrm{H}-\mathrm{D}$ exchange than ethane, and significantly more mono- than bi-deuterated ethene molecules are observed. This observation may indicate that ethene is adsorbed end-on as an ethyl entity on a $\mathrm{Cr}^{3+}$-O moiety, which may either be further hydrogenated to ethane, or, preferably, dehydrogenated back to ethene. Another explanation may be that ethene is deuterated, and subsequently deprotonated, on Brønsted-acid sites on the $\mathrm{Al}_{2} \mathrm{O}_{3}$ support, as has been observed by Amenomiya [20].

The short residence times for surface intermediates, as indicated by the transient experiment (figure 4), are of interest also for a discussion of the rate-determining step of reaction. $20 \%$ ethane conversion, as is typically observed in our experiments, corresponds to a reaction rate of $0.3 \mu \mathrm{mol}$ ethene/s. The catalyst loading (200 mg) and calculated $\mathrm{Cr}$ dispersion (14\%) correspond to exposure of $70 \mu \mathrm{mol} \mathrm{Cr}$ atoms. The apparent turn-over frequency (TOF) is thus $0.004 \mathrm{~s}^{-1}$ at $580{ }^{\circ} \mathrm{C}$. If an elementary step involving an adsorbed hydrocarbon 

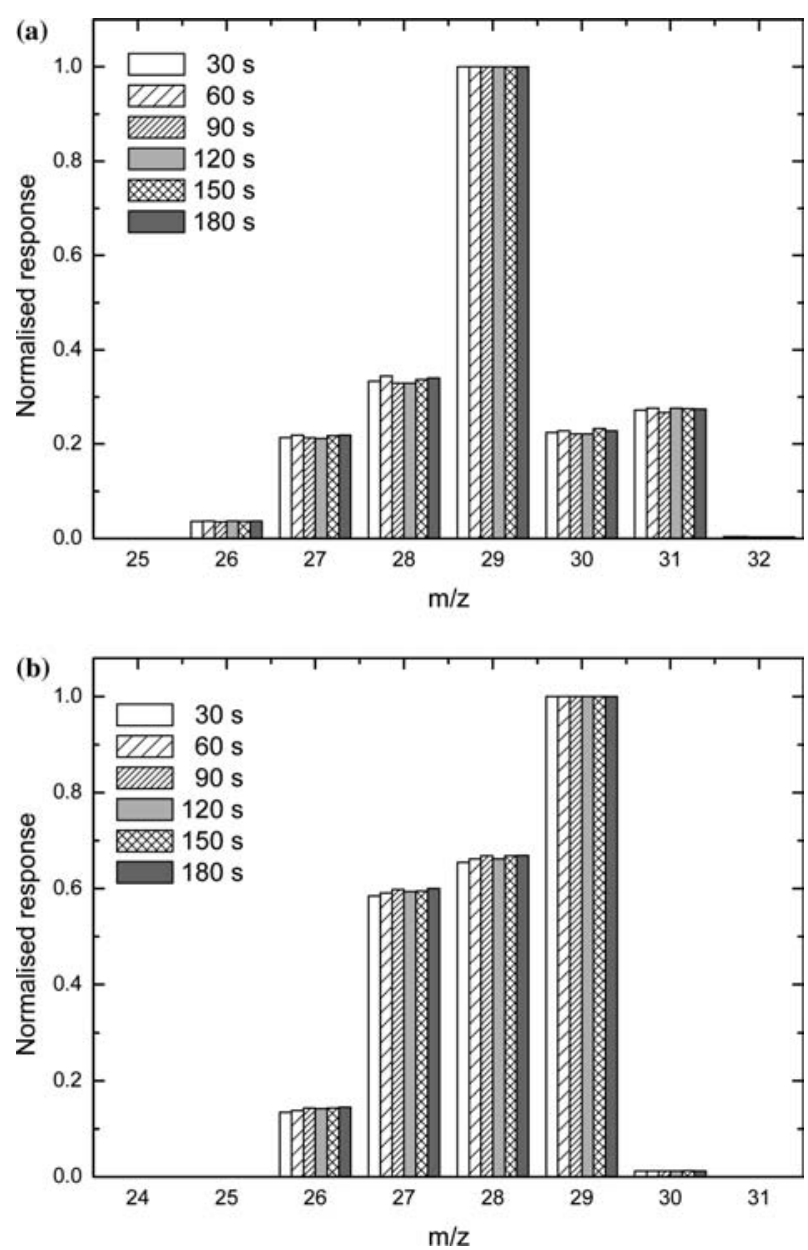

Figure 5. Mass fragmentation pattern of (a) ethane and (b) ethene in the reactor effluent after switching the gas feed from ${ }^{12} \mathrm{C}-\mathrm{C}_{2} \mathrm{H}_{6} / \mathrm{He}$ via $\mathrm{He}$ to $1-{ }^{13} \mathrm{C}_{-} \mathrm{C}_{2} \mathrm{H}_{6} / \mathrm{He}$ over a $13 \mathrm{wt} \% \mathrm{Cr} / \mathrm{Al}_{2} \mathrm{O}_{3}$ catalyst $(200 \mathrm{mg})$ at $580{ }^{\circ} \mathrm{C}, 1 \mathrm{~atm}$, with gas feed composition $\mathrm{C}_{2} \mathrm{H}_{6}: \mathrm{He}=2: 20(\mathrm{Nml} / \mathrm{min})$.

intermediate $(\beta-\mathrm{H}$ transfer or ethene desorption) were the rate-determining step, the intermediate would have a residence time of nearly $4 \mathrm{~min}$ on the surface. This is far from the observed situation, where no significant difference is observed between the tailing of the m/e 27 and $\mathrm{m} / \mathrm{e} 28$ fragments. (As evidenced by the fragmentation patterns shown in figure 3, the presence of etheneforming intermediates on the surface would lead to a delay in the tailing of the $\mathrm{m} / \mathrm{e} 27$ fragment compared to the $\mathrm{m} / \mathrm{e} 28$ fragment during the transient.) Repeating the experiment at $500{ }^{\circ} \mathrm{C}$ gave the same result. In conclusion, the transient experiments indicate that neither $\beta-\mathrm{H}$ transfer of an ethyl species, nor ethene desorption, is the rate-limiting step of reaction. This result is different from that reported by $\mathrm{Kao}$ et al. for isobutane dehydrogenation over pure $\mathrm{Cr}_{2} \mathrm{O}_{3}$, where $\beta$-H transfer was concluded to be the rate-determining step [21]. In fact, since the rate constant of desorption may be expressed as: $\mathrm{k}=v^{*} \exp \left(-\mathrm{E}_{\mathrm{d}} / \mathrm{RT}\right)$, where $v$, the frequency factor of surface intermediates, is normally in the order of $10^{13} \mathrm{~s}^{-1}$, the observed TOF would necessitate an activation energy of $251 \mathrm{~kJ} / \mathrm{mol}$ in order for desorption of any surface species to be the rate-limiting step. This number is significantly higher than that reported for ethane dehydrogenation over a similar $\mathrm{Cr} / \mathrm{SiO}_{2}$ catalyst, i.e., $117 \mathrm{~kJ} / \mathrm{mol}$ [22]. Together, when assuming that all surface $\mathrm{Cr}$ sites are active, the results obtained in this work indicate that ethane adsorption is the rate-limiting step of reaction over a $\mathrm{Cr} / \mathrm{Al}_{2} \mathrm{O}_{3}$ catalyst. Turning again to the recent theoretical work of Lillehaug et al. [13], this conclusion would favour the hydridocomplex route, in which ethane is adsorbed onto a $\mathrm{Cr}-\mathrm{H}$ site, leading to the formation of $\mathrm{Cr}-\mathrm{C}_{2} \mathrm{H}_{5}$ and a hydrogen molecule, with subsequent reformation of $\mathrm{Cr}-\mathrm{H}$ and release of ethene.

\section{Conclusions}

The following conclusions can be drawn from this work:

(1) Ethane dehydrogenation of supported chromium oxide catalysts proceeds via an end-on, dissociative adsorption of ethane on $\mathrm{Cr}^{3+}-\mathrm{O}$ active site at the catalyst surface. This experimental finding confirms the results reported by Burwell et al. for higher 


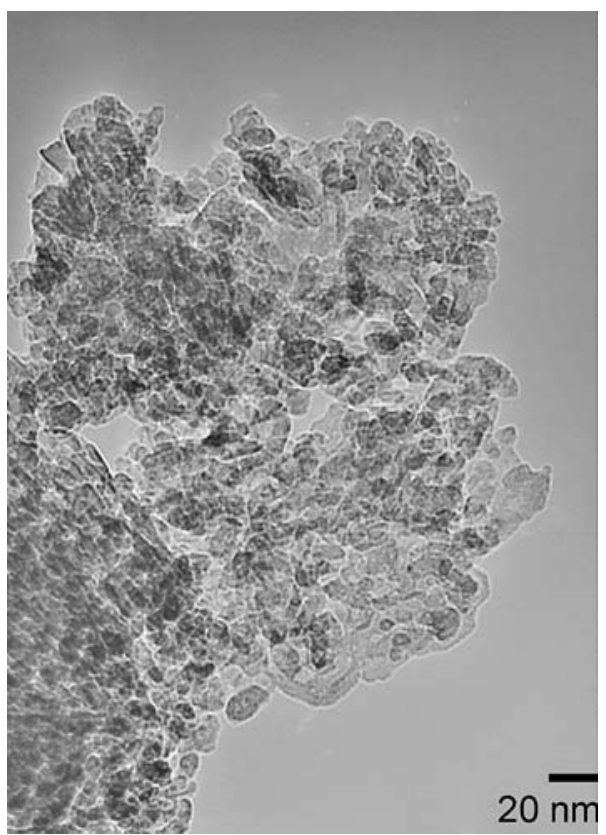

Figure 6. TEM micrograph $(\times 200 \mathrm{k})$ of used $13 \mathrm{wt} \% \quad \mathrm{Cr} / \mathrm{Al}_{2} \mathrm{O}_{3}$ catalyst showing alumina agglomerates with $\mathrm{Cr}$-oxide particles.

alkanes on $\mathrm{Cr}_{2} \mathrm{O}_{3}$ [12] and the recent theoretical work of Lillehaug et al. [13].

(2) We found no evidence that coke deposits formed during the initial activation of the catalyst material are involved in the ethane dehydrogenation cycle since no isotopic scrambling of ethylene was observed.

\section{Acknowledgments}

The Ph.D. grant of A.V. is financed by Statoil through the VISTA programme, contract no. 6446. The research of B.M.W. is supported by Van der Leeuw and VICI grants of NWO-CW.

\section{References}

[1] M.M. Bhasin, J.H. McCain, B.V. Vora, T.T. Imai and P.R. Pujado, Appl. Catal. A General 221 (2001) 397.

[2] F. Buonomo, D. Sanfilippo, F. Trifiro, in: Handbook of Heterogeneous Catalysts, Vol. 5, eds. G. Ertl, H. Knozinger and J. Weitkamp (VCH, Weinheim, 1997) p. 2140, and references therein.

[3] B.M. Weckhuysen and R.A. Schoonheydt, Catal. Today 51 (1999) 223and references therein.

[4] B.M. Weckhuysen, I.E. Wachs and R.A. Schoonheydt, Chem. Rev. 96 (1996) 3327and references therein.

[5] E. Groppo, C. Lamberti, S. Bordiga, G. Spoto and A. Zecchina, Chem. Rev. 105 (2005) 115and references therein.

[6] S.M.K. Airaksinen, M.E. Harlin and A.O.I. Krause, Ind. Eng. Chem. Res. 41 (2002) 5619.

[7] A. Hakuli, M.E. Harlin, L.B. Backman and A.O.I. Krause, J. Catal. 161 (1996) 393.

[8] S. DeRossi, G. Ferraris, S. Fremiotti, E. Garrone, G. Ghiotti, M.C. Campa and V. Indovina, J. Catal. 148 (1994) 36.

[9] R.L. Puurunen and B.M. Weckhuysen, J. Catal. 210 (2002) 418.

[10] F. Cavani, M. Koutyrev, F. Trifiro, A. Bartolini, D. Ghisletti, R. Iezzi, A. Santucci and G. DelPiero, J. Catal. 158 (1996) 236.

[11] R.L. Burwell, G.L. Haller, K.C. Taylor and J.F. Read, Adv. Catal. 20 (1969) 1.

[12] R.L. Burwell, A.B. Littlewood, M. Dardew, G. Pass and C.T.H. Stoddard, J. Am. Chem. Soc. 82 (1960) 6272.

[13] S. Lillehaug, K.J. Borve, M. Sierka and J. Sauer, J. Phys. Org. Chem. 17 (2004) 990.

[14] G. Mestl, N.I. Maksimova, N. Keller, V.V. Roddatis and R. Schlogl, Angew. Chem. Int. Ed. 40 (2001) 2066.

[15] N. Keller, N.I. Maksimova, V.V. Roddatis, M. Schur, G. Mestl, Y.V. Butenko, V.L. Kutznetov and R. Schlogl, Angew. Chem. Int. Ed. 41 (2002) 1885.

[16] A. Hakuli, A. Kytökiwi and A.O.I. Krause, Appl. Cat. A: General 190 (2000) 219.

[17] T.A. Nijhuis, S.J. Tinnemans, T. Visser and B.M. Weckhuysen, Phys. Chem. Chem. Phys. 5 (2003) 4361.

[18] T.A. Nijhuis, S.J. Tinnemans, T. Visser and B.M. Weckhuysen, Chem. Eng. Sci. 59 (2004) 5487.

[19] S.J. Tinnemans, M.H.F. Kox, T.A. Nijhuis, T. Visser and B.M. Weckhuysen, Phys. Chem. Chem. Phys. 7 (2005) 211.

[20] Y. Amenomiya, J. Catal. 12(2) (1968) 198.

[21] J.-Y. Kao, H. Piet-Lahanier, E. Walter and J. Happel, J. Catal. 133 (1992) 383.

[22] H.J. Lugo and J.H. Lunsford, J. Catal. 91 (1985) 155. 